\title{
Geodiversity geological and geomorphological of the municipality of Paraúna, central- southern Goiás state, Brazil
}

\author{
Keywords \\ Geology \\ Geomorphology \\ Geodiversity sites \\ Geoconservation \\ Earth
} Abstract
The research area of the present study was the municipality of Paraúna, Goiás
state, Brazil, in the mesoregion of Southern Goiás, Vale do Rio dos Bois
microregion. Paraúna stands out for its great tourist potential, having various
tourist attractions such as the geological structure Ponte de Pedra, the
mountains Serra do Galés and Serra da Portaria, among others. The State
Park of Paraúna, created by the law-decree $\mathrm{N}^{\circ} 5.568$ of March 18th, 2002, is
also part of this municipality. This study aimed to analyze and discuss the
geodiversity based on geology and geomorphology of Paraúna. The term
geodiversity consists of a variety of landscapes, geological environments, rocks,
soils, fossils, minerals and other surface deposits that support life on Earth.
We identified and mapped seven Geodiversity sites in the northern region of
Paraúna municipality.

\section{INTRODUCTION}

Geodiversity is defined as the variety of environments, phenomena, and active processes of geological character which create landscapes, rocks, minerals, fossils, soils, and other superficial deposits that constitute the basis for life on Earth (STANLEY, 2000). According to Gray (2004), Geodiversity is a powerful structure for the integration of Earth Sciences, allowing us to observe rocks, minerals, sediments, fossils, landforms, soils, and processes to understand the geosphere with a range of roles and values that need protection and conservation.

Brilha (2005) refers to Geological Heritage as the set of geosites (or areas of geological interest - Geodiversity sites; sensu BRILHA, 2016) inventoried and characterized in a given region, with geographically well-delimited local geosites, where one or more elements of Geodiversity have a unique value from the viewpoint of scientific, pedagogical, cultural, and tourist aspects. It integrates all the elements that constitute Geodiversity, encompassing Paleontological Heritage, Mineralogical Heritage, Geomorphological Heritage, Petrological Heritage, Hydrogeological Heritage, among others.

Reynard and Brilha (2018) consider that in the last 25 years there has been a growing scientific interest in topics related to Geological Heritage and a large set of territorial initiatives emerged worldwide. Brilha (2016) argues that not all elements of Geodiversity have the same importance for society and science, as the criteria that distinguish them are variable, such as their representativeness, integrity, rarity, associated scientific knowledge, scenic beauty, interpretive potential, security, accessibility, among others. These are the criteria that give dimension to the previously mentioned values of Geodiversity.

Despite not having a high value for science, many elements of geodiversity, whether of

${ }^{1}$ Federal University of Goiás, Brazil. brunomartins-2009@hotmail.com

${ }^{2}$ Federal University of Goiás, Brazil. claudia@ufg.br

${ }^{3}$ Federal University of Goiás, Brazil. candeiro@ufg.br 
geological or geomorphological interest, are important for educational and tourist purposes or for the culture and identity of the communities where they are located. These elements of Geodiversity can be ex situ or in situ, and are then called Geodiversity sites (BRILHA, 2016). As previously mentioned, these sites cannot be considered as geoheritage because they lack recognition from the national or international scientific community.

The municipality of Paraúna has a total area of $3,779,385 \mathrm{~km}^{2}$ and a population of nearly 10,863 inhabitants, according to the 2010 Brazilian demographic census carried out by the Instituto Brasileiro de Geografia e Estatistica. Paraúna is located $157 \mathrm{~km}$ from the city of Goiânia, in the south-central region of Goiás State, and is placed at the northern portion of the Paraná Basin

(https://www.parauna.go.gov.br/pagina/151geografia-do-municipio). The Paraná Basin is an area of important geodiversity which resulted from a long and complex geological evolution (from Paleozoic to Recent), and is endowed with landscapes of significant tourist attractiveness. Until today, Paraúna's geology has been the focus of countless scientific studies by regional research groups (FERREIRA 2016; FERREIRA; LIMA 2018). The area also serves as a "base camp" for scientific expeditions and field trips by student groups of Natural Sciences.

The foundations of the municipality of Paraúna started at the beginning of the 20th century inside the territory of Palmeiras de Goiás municipality. The first inhabitants built a ranch made of straw thatch to be a place where one could pray the Rosary on the banks of the São José river. In this context, the village that received the name of "Bota Fumaça" was instituted (PARAÚNA, 2007a).

Later, the village became a district named "São José do Turvo". In 1930 the name was changed again and now it would be called "Paraúna", a word from the Tupi language that means Black River $($ Para = river - Una = black $)$ (PARAÚNA, 2007a). According to the Instituto Brasileiro de Geografia e Estatística (IBGE, 2011) data for the year of 2010, the total population of Paraúna is approximately 10.863 inhabitant, where 2.876 live in the rural area and 7.987 are in the urban area. The demographic density of Paraúna is 2.77 (hab/km).

According to Ab'Saber (1983), the municipality has two well-defined seasons: a rainy summer and a very dry winter. Overall, Paraúna has tropical semi-humid conditions where the average temperature of the coldest month is higher than $18^{\circ} \mathrm{C}$, the average temperature of the warmest month is around $30^{\circ}$ $\mathrm{C}$, and the annual average temperature is $22^{\circ} \mathrm{C}$. The rainy season occurs from September to April and it is also the season where the highest temperatures are reached. The dry season goes from May to August.

There are several mountains in the municipality: the Serra das Divisões or Santa Marta in the south, the hillside of Araguaia in the northeast, Serra da Portaria and Serra das Galés in the central part of Paraúna, and Serra da Arnica and Serra do Quebradão in the north. The drainage network is formed by the rivers Desengano, Couro do Cervo, Ponte de Pedra, Preto, Verdão, Bois, Paranaíba, Ribeirão Formoso, Córrego do Macaco, Córrego Jaguanez, Córrego da Divisa, and Córrego Bernardino (FERREIRA, 2016).

According to Ribeiro and Walter (2008), the vegetation coverage of Paraúna is closely related to climatic and pedological characteristics as well as humidity and topography of the region. Grasslands, Brazilian savannas (cerrados), woods and gallery forests are part of the scenery, although most of the original vegetation has been replaced by pastures and agricultural fields.

The Paraúna State Park (PEPa) is the main conservation area in the municipality of Paranúna and was created by the Law Decree No. 5568 , of March 18, 2002. The park is located in the northwest of the state, between the geographic coordinates $16^{\circ} 56$ 'to $17^{\circ} 02^{\prime}$ south latitude and $50^{\circ} 36$ 'to $50^{\circ} 42^{\prime}$ west of Greenwich, at altitudes ranging from 690 to 890 meters, with an approximate area of 3,250 hectares. PEPa has an area of approximately 3250 acres that includes the mountains Serra das Galés and Serra da Portaria. According to SEMAD (2019), PEPa was created to preserve two geological monuments found in the park area. These features are part of the history of the region's population in addition to being an unmistakable tourist attraction.

The present work amied at surveying the Geodiversity sites at municipality of Paraúna based geological a geomorphological features, since it is believed that the didactic use favors the development of conservation measures. It is worth emphasizing that conducting other important works more effectively will knowledge of local heritage, while at the same time assisting in the development of the awareness of the need to conserve natural heritage.

\section{METHODS}

The methodology used to achieve the objectives 
proposed here consists of: bibliographic review, fieldwork, mapping and inventory of the Geodiversity sites using the methodological proposals of Brilha (2016) and Borba et al. (2013) adapted to the studied area and considering the sites which have exceptional characteristics for the inventory process.

The methodology of Brilha (2016) used here to inventory the Geodiversity sites consists of a review of the available bibliography on the geology and geomorphology of the studied area as well as field works and consultation with specialists who worked in the same area. For the inventory of sites of educational value, the research aimed at those that have been or are used in educational activities by educational institutions. For the sites of tourist value, we consulted professional tourist guides in Paraúna municipality, websites, and tourist offers in brochures. To better understand the values for tourist and educational purposes, the following criteria were also used: accessibility, usage limitations, safety, and scenery. To assess the potential Tourist Value, the following criteria were also considered: interpretive potential, economic level, and proximity to recreational areas (BRILHA, 2016).

The bibliographic review consisted of the review of books, articles published in periodicals and annals of congresses, and national and international sites on topics related to geoconservation, geological heritage, and geotourism. Furthermore, bibliographic research also included a discussion about the tools that support geoconservation: geoparks, Geodiversity sites, and educational approaches. The selected references about the municipality of Paraúna included studies on the local geography, and about historical and cultural aspects that emphasize the importance of the studied area.

Seven fieldworks with different objectives were carried out during this research. Some expeditions were made to identify the studied area and check the geological and geomorphological units. Some fieldworks were made to visit and interview municipal agencies and other visits aimed the georeferencing, identification and inventoring of the geological formations that compose the Geodiversity sites of the studied area. The surveyed sites were georeferenced by GPS and photographs of the visited areas were taken during all stages listed here.

The physical characterization of the Paraúna municipality was made by the compilation of the mappings made for the municipality, especially geological and geomorphological maps.

The identification and characterization of the
Geodiversity sites: osite identification followed the methodology described by Brilha (2016). O autor aborda que a inventariação é o primeiro passo a ser feito para identificar o geossítio. Deve ser realizada de forma sistemática em toda área de estudo, depois de um reconhecimento.

To complement Brilha (2016) we also used the proposal of Borba et al. (2013) (where the authors considered Geodiversity sites [= geosites in Borba et al. op. cit.]) and all natural outcrops, main geographical accidents, roadblocks on paved roads, active and/or abandoned quarries and mines, as well as strategic points on highways to act as lookouts were considered. Also for this inventory, it was considered the localities: (a) described, represented or cited in relevant scientific publications or regional geological maps (e.g. FERREIRA, 2016; FERREIRA; LIMA, 2018); (b) geological and/or geomorphological areas of interest usually used for practical classes (field trips) in any sub-area of Geosciences (e.g. General Geology, Stratigraphy, Sedimentology, Material and Methods of Earth Sciences) that exemplify significant features (didactic interest); (c) where stratigraphic units, ages, and other relevant geological information have been identified, defined, obtained or named.

\section{GEOLOGICAL SETTING}

\section{Brief presentation of the Geology from Paraúna}

According to Goiás (2008), the rocks in the municipality of Paraúna at Parque Estadual de Paraúna are dated from the Neoproterozoic Period. However, the topography of Paraúna was shaped by the lithology of the Paraná Sedimentary Basin. The Paraná Basin is an extensive intracratonic structure formed over the continental crust, occupying an area of approximately $1.400 .000 \mathrm{~km}^{2}$ that covers part of the territories of Brazil, Argentina, Uruguay, and Paraguay (MILANI et al., 1998). The development of the Paraná Basin is related to the Gondwana fragmentation, where the initial sedimentation is dated from the Ordovician and lasted until the Lower Cretaceous (SCHNEIDER et al., 1974). The geological records from the Paraná Basin in Goiás are represented by the Piranhas Formation and the groups Rio Ivaí, Paraná, Itararé (Aquidauana Formation, Furnas), São Bento (Botucatu and Serra Geral formations), and Bauru (Adamantina and Marília formations; sensu FERNANDES; COIMBRA, 1996).

The predominant rocks in the municipality of 
Paraúna are from the orthogneisses of the Oeste de Goiás Unity, Aquidauana Formation, Serra Geral Formation, Adamantina Formation, and some indefinite detrital cover. There are also fewer rocks from the Furnas, Cachoeirinha, Botucatu, and Santo Antônio da Barra formations, the metavolcanosedimentary sequence of Anicuns-Itaberaí, and alluvial deposits (GOIÁS, 2006).

\section{Short presentation of the Geomorphology from Paraúna}

The geomorphological mapping of the Goiás State (GOIÁS, 2006) classifies the topography of the municipality of Paraúna as horizontal and subhorizontal platforms. According to Goiás (2006), the rocks of the Paraná Basin were subjected to regional planation processes and the predominant units are the Regional Planation Surfaces associated with Tabular Reliefs. Casseti (2005) addresses an example of tabular relief on the northern edge of the Paraná Sedimentary Basin, and mentions the municipality of Paraúna featuring Carboniferous sedimentary sequences of the Aquidauna Formation that are under crystalline, pre-Cambrian structures (gneisses of the Goiás Complex and mica schists from the Araxá Group), covered or not by JurassicCretaceous deposits of the São Bento Group or Cretaceous deposits of the Bauru Group. This geomorphology evolved in sedimentary rocks forming poorly to mildly dissected plateaus and large interfluves, resulting in a rather monotonous relief. The relief is also correlated with the basaltic flows of the Serra Geral Formation associated with the subhorizontal structures of the Paraná Basin.

\section{RESULTS}

Geodiversity sites at Parque Estadual de Paraúna are important areas to preserve local geodiversity. Here we identified seven Geodiversity sites based in Brilha (2016) and adapted from Borba et al. (2013). Box 1 shows the name, locality and geological unity of Paraúna's Geodiversity sites.

Box 1. Geodiversity sites of the municipality of Paraúna.

\begin{tabular}{|c|c|c|}
\hline $\begin{array}{l}\text { Geodiversity } \\
\text { site }\end{array}$ & Locality & Geological Unity \\
\hline $\begin{array}{l}\text { Serra da } \\
\text { Portaria }\end{array}$ & $\begin{array}{l}\mathrm{S} 16^{\circ} 5809 \\
\mathrm{~W} 50^{\circ} 4510\end{array}$ & $\begin{array}{c}\text { Aquidauana and Adamantina } \\
\text { formations }\end{array}$ \\
\hline $\begin{array}{l}\text { Muralha de } \\
\text { Ferro }\end{array}$ & $\begin{array}{l}\text { S } 16^{\circ} 5797 \\
\text { W } 50^{\circ} 4331\end{array}$ & Serra Geral Formation \\
\hline Ponte de Pedra & $\begin{array}{l}\mathrm{S} 17^{\circ} 1036 \\
\mathrm{~W} 50^{\circ} 5008\end{array}$ & Adamantina Formation \\
\hline Serra das Galés & $\begin{array}{c}\mathrm{S} 16^{\circ} 5932 \\
\mathrm{~W} 50^{\circ} 3736\end{array}$ & Aquidauana Formation \\
\hline $\begin{array}{l}\text { Cachoeira do } \\
\text { Cervo }\end{array}$ & $\begin{array}{c}\mathrm{S} 16^{\circ} 5239 \\
\mathrm{~W} 50^{\circ} 5320\end{array}$ & Aquidauana Formation \\
\hline $\begin{array}{l}\text { Cachoeira dos } \\
\text { Sonhos }\end{array}$ & $\begin{array}{l}\mathrm{S} 16^{\circ} 5700 \\
\mathrm{~W} 50^{\circ} 4814\end{array}$ & Aquidauana Formation \\
\hline Cristo Paredão & $\begin{array}{l}\mathrm{S} 16^{\circ} 5703 \\
\mathrm{~W} 50^{\circ} 2649\end{array}$ & Botucatu Formation \\
\hline
\end{tabular}

Org: the authors, 2019.

Regarding the geology of the area (Figure. 1) shows that the Geodiversity sites are located in three geological units: Itararé Group
(Aquidauana Formation), São Bento Group (Botucatu Formation), and Bauru Group (Adamantina Formation). 
Figure 1. Geological units in Paraúna municipality; dotted/continuous green area refers to Paraúna State Park. Aquidauana Formation, Serra Geral Formation (ROSETTI et al. 2018), Adamantina Formation (sensu FERNANDES; COIMBRA, 1996).
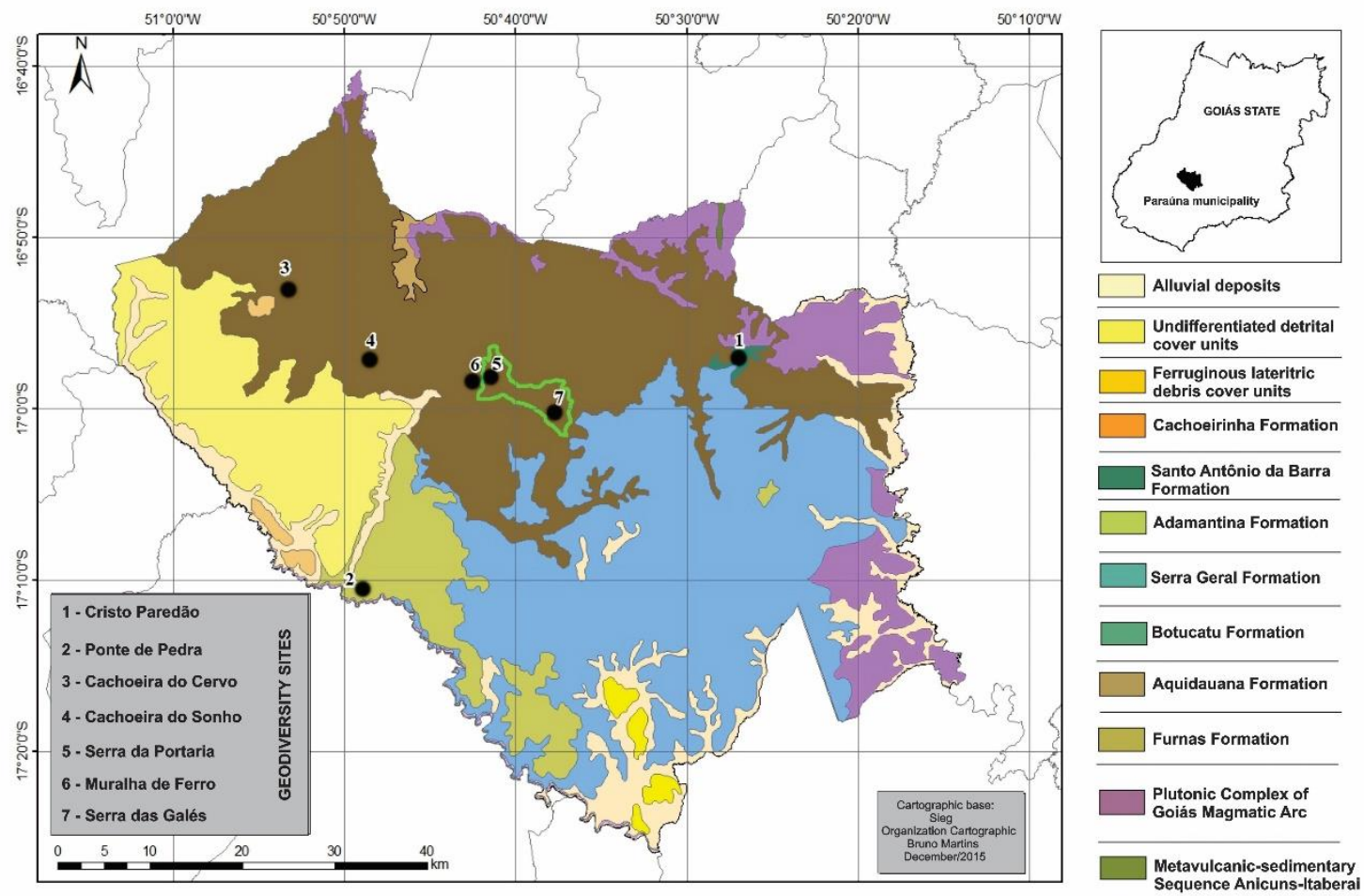

Org: Ferreira (2016).

The Aquidauana Formation is considered Permo-Carboniferous in age (RADAM BRASIL, 1982). According to Goiás (2008), this unity is located in Southwestern Goiás State and is 300 $\mathrm{km}$ in length according $\mathrm{E}-\mathrm{W}$ and $65 \mathrm{~km}$ in width from nearby Paraúna to Mato Grosso State. This unit is composed of conglomerates of quartz and sandstone pebbles. Most rocks are reddish-purple and comprise medium to thick sandstone beds that are friable with some feldspar inclusions, and show trough cross-stratification. There are also local silicified levels with white thick sandstones as well as conglomerates (diamictites) followed by finely layered siltstones and argillites, and red to grayish-green shales. Rhythms formed by thin levels of argillite, siltite, and fine sandstone are also observed in this unity (GOIÁS, 2008). The Aquiduana Formation is located at northwestern Paraúna and is one of the most representative units in areal terms. The main Geodiversity sites are located in the residuals with steep edges and rugged areas produced by erosion. Considering the geomorphological aspect, these features present shapes of animals and objects.

In the Goiás State, the Serra Geral Formation (ROSETTI et al., 2018) extends to Itumbiara town, reaching the surroundings of Paraúna and forming linear bands along the beds of the rivers
Claro, Corrente, Aporé, and Verde. The lithotypes are tholeitic basalts with subordinate volcanic rhyolitic and rhyodacitic rocks (ROSETTI et al. 2018). The basalts form a thin, homogeneous, dark grey, massive flat relief that occasionally presents amygdaloids and columnar disjunction (GOIÁS, 2008). The Serra Geral Formation was dated as Lower Cretaceous in age by Rossetti et al.(2018). The Serra Geral Formation occurs in the south-central portion of Paraúna. The geomorphological features of the Paraúna Geodiversity sites present waterfalls.

The Adamantina Formation is dated from the Upper Cretaceous (Turonian-Santonian) (DIASBRITO et al., 2001). It occupies the southern and southwestern areas of the Goiás State, including the Emas National Park and the municipalities of Rio Verde, Itarumã, Cachoeira Alta, Serranópolis, Caçu, and Quirinópolis. According to Fernandes and Coimbra (1996), this geological unity is formed by massive, light grey, beige or pinkish sandstones that are fine to very fine-grained (sometimes medium-grained), mostly poorly sorted and showing subordinate plane-parallel cross-stratification. The lithological and sedimentary characteristics indicate that the sedimentation environment is fluvio-lacustrine. This formation is located in the southeast region 
of Paraúna. Due to the calcitic matrix of this unit, it may present karst features.

\section{Description of the Geodiversity sites}

After applying the methodological procedures and performing the inventory methodology of Brilha (2016) for Geodiversity sites, seven sites were selected. Their geoform, which constitutes the main attraction for the category of the site, are highlighted in Table 2. Regarding the main attraction of the inventoried sites, the geoforms (goblet, turtle, anvil, brain, stone soldier, indian woman) stone sidewalk, residuals, and waterfalls stand out.

Box 2. Geodiversity Sites of the municipality of Paraúna.

\begin{tabular}{|c|c|c|}
\hline Geodiversity Site & Main attraction & Potential \\
\hline Geodiversity Site 1: Cristo Paredão & Residual & $\begin{array}{c}\text { Educational } \\
\text { Tourist }\end{array}$ \\
\hline Geodiversity Site 2: Ponte de Pedra & Cave & $\begin{array}{c}\text { Educational } \\
\text { Tourist }\end{array}$ \\
\hline Geodiversity Site 3: Cachoeira do Cervo & Riptide & Tourist \\
\hline Geodiversity Site 4: Cachoeira do Sonho & Waterfall & Tourist \\
\hline Geodiversity Site 5: Serra da Portaria & Residual & $\begin{array}{c}\text { Educational } \\
\text { Tourist }\end{array}$ \\
\hline Geodiversity Site 6: Muralha de Ferro & Staircase of rocks & $\begin{array}{c}\text { Educational } \\
\text { Tourist }\end{array}$ \\
\hline Geodiversity Site 7: Serra das Galés & Geoforms & $\begin{array}{c}\text { Tourist } \\
\text { Educational }\end{array}$ \\
\hline
\end{tabular}

Org: the authors, 2019.

\section{Geodiversity Site 1: Cristo Paredão}

The stone wall Cristo Paredão is located in the urban area of Paraúna and belongs to the Botucatu Formation. This uniform relief (Figure 2 ) is an important and easily accessible tourist attraction that is regularly visited. The height of Cristo Paredão is approximately 100 meters. Standing out for its aesthetic value, this large stone wall is significant to the scenery of Paraúna city. In its vicinity, there isthe City Hall, the
Public Forum, and the main administrative buildings of Paraúna. The residents of Paraúna consider Cristo Paredão the postcard scenery of the city. It also has a cultural value for being a spot where the local population attends religious manifestations in the chapel located at the top of the relief. According to residents, the chapel was built in 1950 as retribution to the grace received by Mrs. Otavila de Souza Melo. In this chapel, the traditional Novena Masses to Nossa Senhora da Guia are celebrated. 
Figure 2. Jesus Christ Statue and chapel of Cristo Paredão a scenery of the Paraúna town.

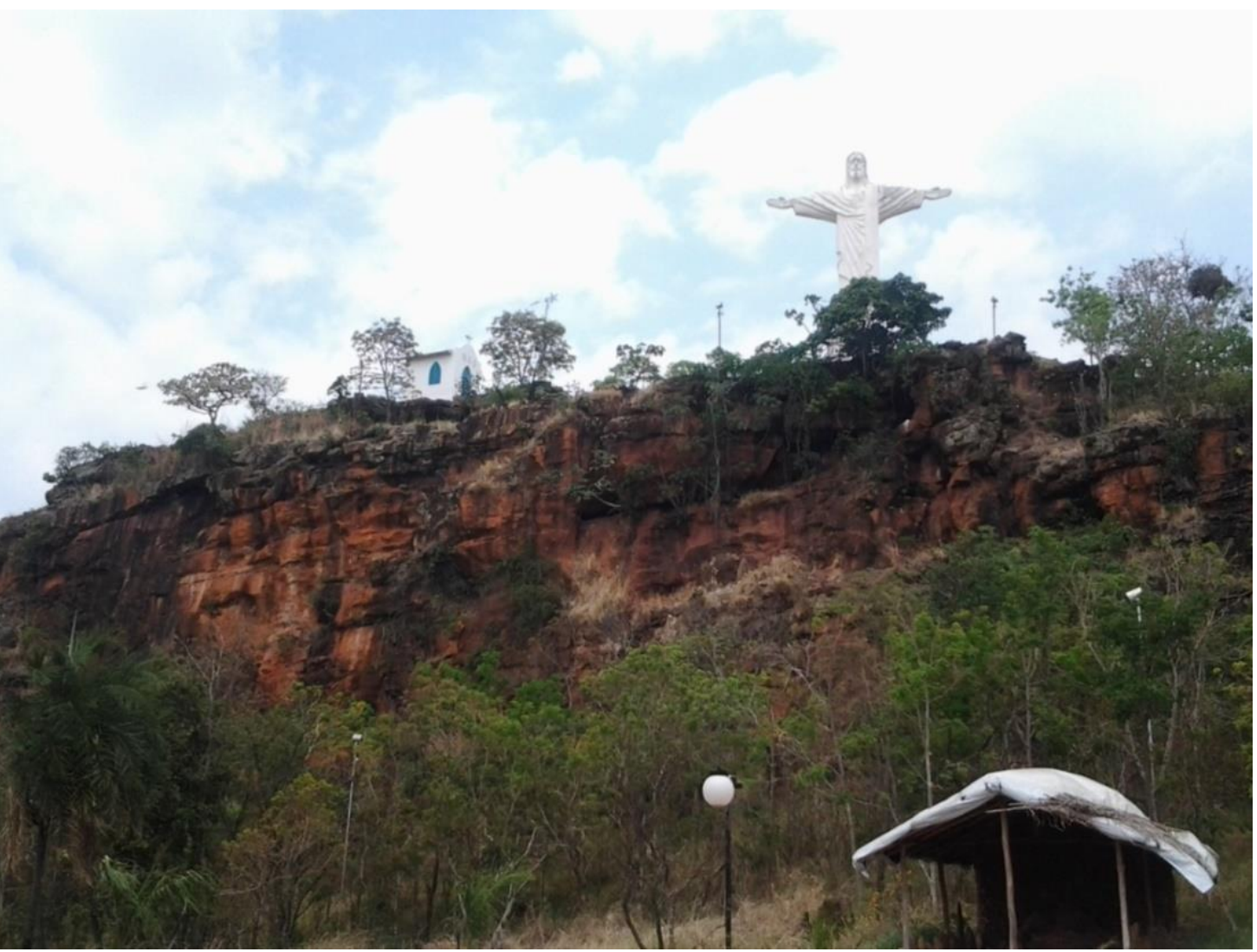

From: Ferreira (2016).

This Geodiversity site presents erosive processes or displacement of sandstone blocks from the Aquidauana Formation. There are no restrictions for its use and is regularly visited by residents and tourists of Paraúna, in addition to having easy access and security. This site is the most visited area by educational institutions, mostly for its easy access (since it is located in the central area of the city) and for presenting decent geological strata that are used by teachers.

\section{Geodiversity Site 2: Ponte de Pedra}

Ponte de Pedra (Figure 3) is approximately $60 \mathrm{~km}$ from Paraúna and is part of the Adamantina Formation. The river runs through large cliffs surrounded by dense vegetation and drains into a rectangular passage, in free fall, forming a small waterfall at the entrance of a cave located under the relief. The waterfall is used for leisure by visitors, has easy access and adequate infrastructure. According to the Tourism Inventory of Paraúna (2007a), the geological unity is formed by calcareous rocks that reach 100 meters long. However, the description of Goiás (2008) classifies the rocks of the Adamantina Formation as massive, light grey, beige or pinkish sandstones that are fine to very fine-grained (sometimes medium-grained), mostly poorly sorted and show subordinate plane-parallel crossstratification. These sandstones likely have a calcareous matrix, which explains the formation of the cave.

This Geodiversity site presents erosive processes or displacement of sandstone blocks from the Adamantina Formation. It has no restrictions for its use and is commonly visited by residents and tourists from Paraúna. Itsaccess is secure and has an intermediate degree of difficulty. 
Figure 3. Ponte de Pedra I Geodiversity site berring-rock in Adamantina Formation geological area.

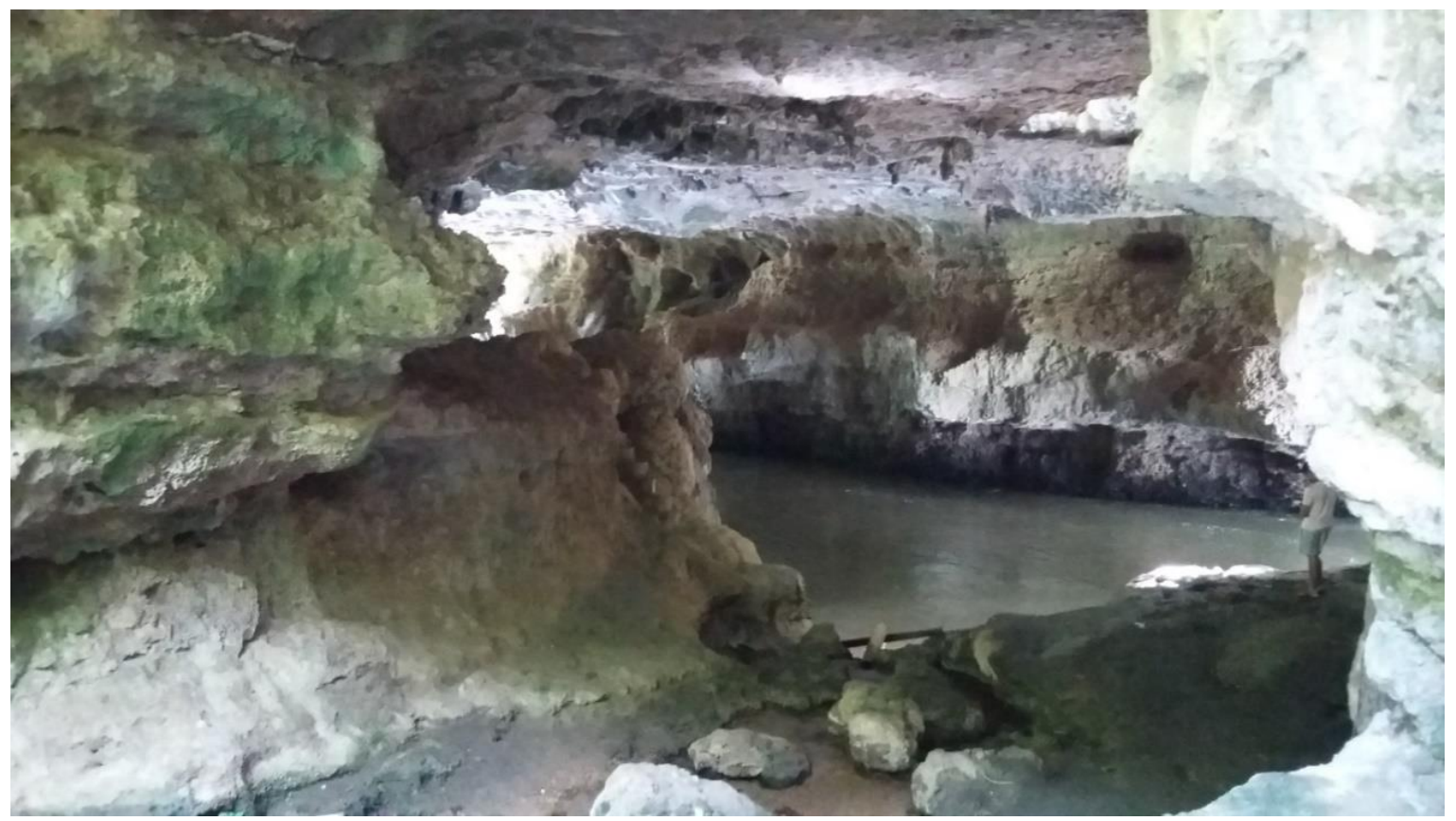

Source: Ferreira (2016).

Geodiversity Site 3: Cachoeira do Cervo

The waterfall Cachoeira do Cervo (Figure 4) is 64 $\mathrm{km}$ away from Paraúna. The local population uses the area for leisure but there is no infrastructure and the access is very difficult. The waterfall is formed by the Couro do Cervo River, it has approximately 12 meters high and 25 meters wide, and great aesthetic value. Local residents question the lack of infrastructure that makes it almost inaccessible for the population and tourists.

This Geodiversity site does not present erosive processes or displacement of sandstone blocks from the Aquidauana Formation. There are no restrictions on its use. Currently, its access is difficult due to road conditions.

Figure 4. Cachoeira do Cervo Geodiversity site an importante pontential tourist area in Paraúna municipality.

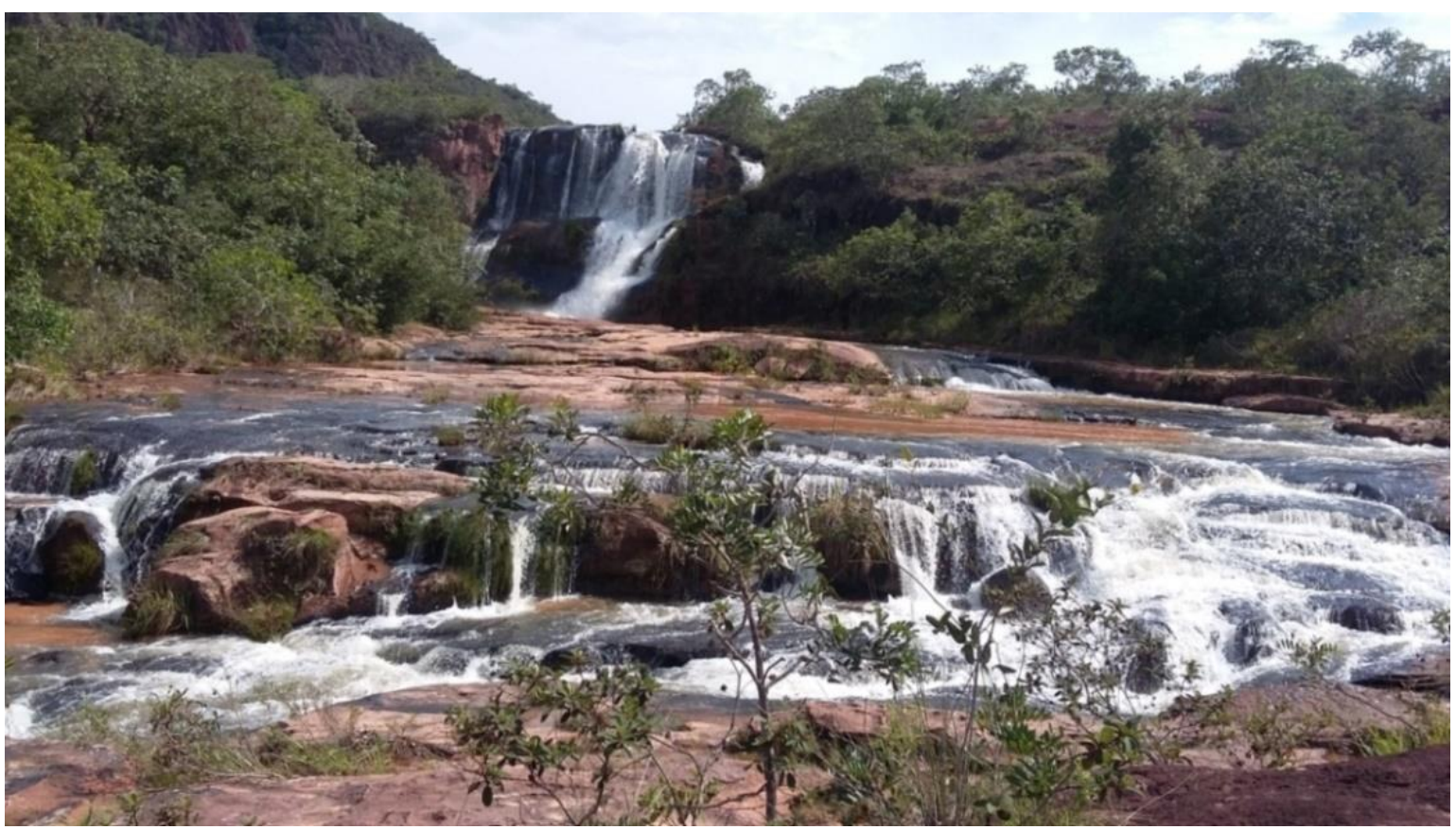

Source: Ferreira (2016). 


\section{Geodiversity Site 4: Cachoeira do Sonho}

The waterfall Cachoeira do Sonho (Figure 5) is 53 $\mathrm{km}$ from Paraúna. It is formed by the crystalline waters of the Desengano River that impute aesthetic value to the site. The area has a sequence of three waterfalls that flow through rocks of the Aquidauana Formation. Local population uses the area for leisure but there is no infrastructure and access is difficult.

This Geodiversity site does not present erosive processes or displacement of sandstone blocks from the Aquidauana Formation. There are no restrictions for its use. Currently, it is difficult to access due to road conditions.

Figure 5. Cachoeira do Sonho Geodiversity site near Paraúna urban area.

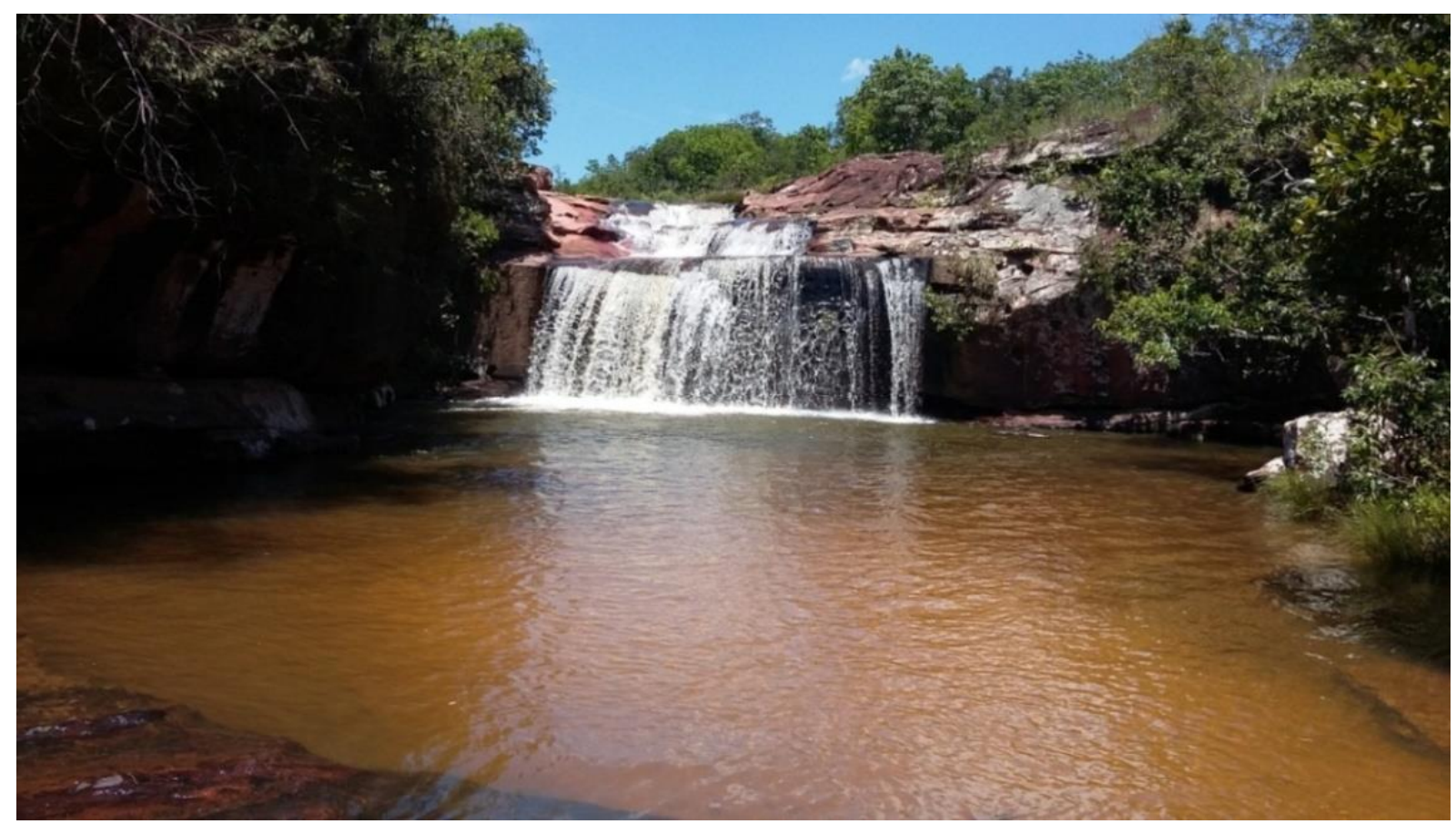

From: Ferreira (2016).

\section{Geodiversity Site 5: Serra da Portaria}

The mountain Serra da Portaria (Figure 6) is 38 $\mathrm{km}$ from Paraúna municipality. Part of the Serra da Portaria is located in the private area of the São Domingos Farm but the access is free of charge for visitors. The Serra da Portaria is carved in rocks of the Aquidauana Formation (see LACERDA et al. 2011) and a minor area in Adamantina Formation. According to the Tourist Guide of Paraúna (2013), the mountain's name is based on the existing scarps that show vestiges of sealed portals. The scarps lead to a Geodiversity site of stunning aesthetic value. The structure of Serra da Portaria is part of the feature of the Tabular Relief. Casseti (1994, p. 73) describes the Serra da Portaria as a silt-sandstone sequence in horizontal concordant structure and demonstrates the genesis of levels or stairs that resulted from differential erosion. In different areas of Serra da Portaria some caves were formed between the rocks, and local residents believe that they form tunnels. Eight caves were cataloged in several areas of Serra da Portaria. According to the Tourism Inventory of Paraúna (2007a), the local population considers this geological unity as a mystical place and some residents report that the area is visited by unidentified flying objects. Another cultural aspect is the Serra da Portaria Institute, located in the area of the mountain. The institute is dedicated to mystical affairs and is a center of reference for the study, research and training of integral therapies.

This Geodiversity site presents erosive processes or displacement of sandstone blocks from the Aquidauana Formation. There are no restrictions for its use and is visited by residents and tourists from Paraúna. Its access is secure and of intermediate difficulty, being highly visited by educational institutions for presenting decent geological strata that are used by teachers. 
Figure 6. Serra da Portaria Geodiversity site which is exposed Paleozoic Aquidauana Formation and Upper Cretaceous Adamantina Formation.

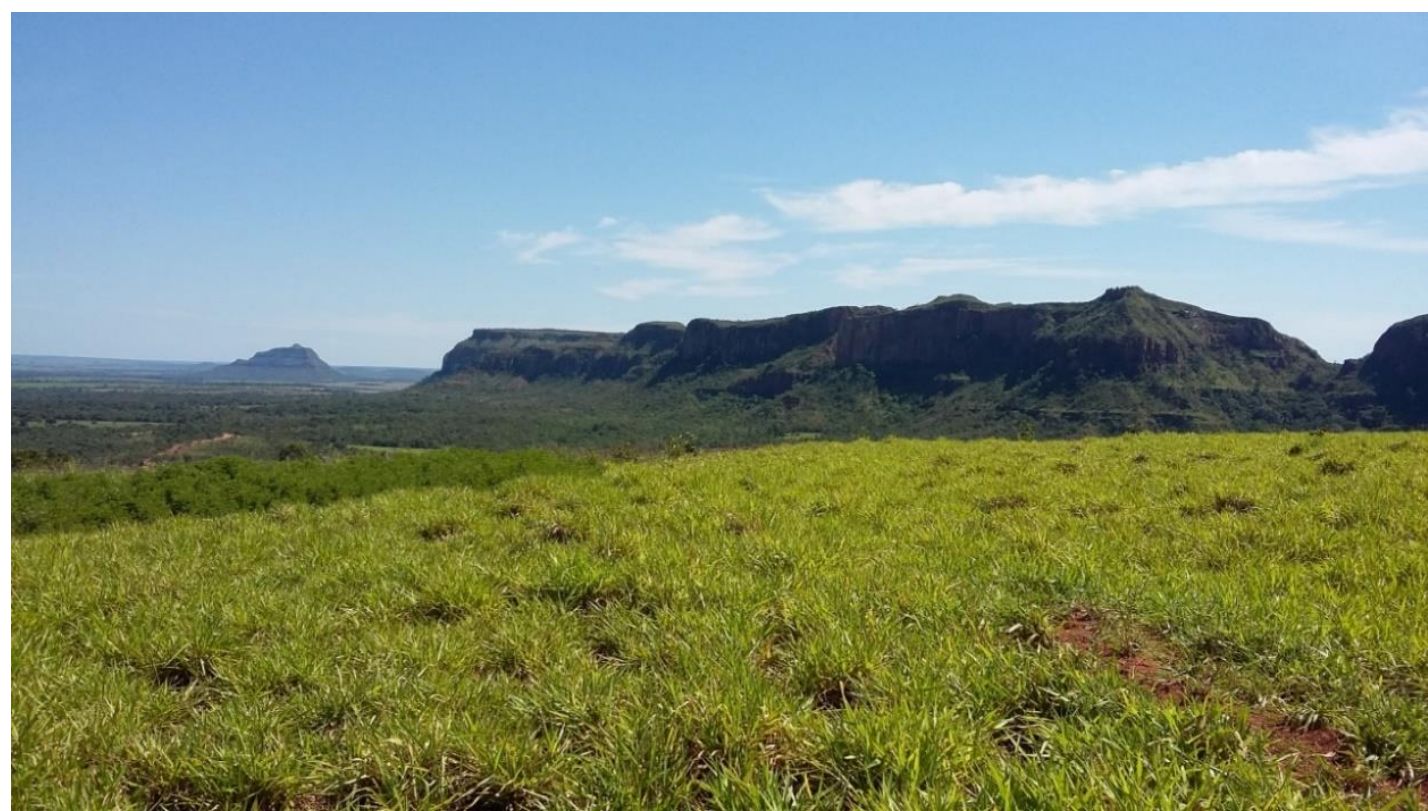

Source: Ferreira (2016).

\section{Geodiversity Site 6: Muralha de Ferro}

The geological formation Muralha de Ferro (Figure 7) is approximately $34 \mathrm{~km}$ from Paraúna. It is composed by a large stone wall forming a stairway with naturally cut and lapidated organized rocks. The stairway is an important element in the attribution of aesthetic value. According to the Tourism Inventory of Paraúna (2007a), Muralha de Ferro is formed by black basaltic rocks, a type of resistant volcanic rock also known as iron-rock (magnetite), that is 1 meter wide, reaching up to 2 meters in height in some areas. To Casseti (1990, p 74) there are diabase dykes of considerable length on which the resulting topographic relief characterizes the popularly known 'wall' that was formed by differential erosion. Therefore, this explains the name Muralha de Ferro (Iron Wall). This geological unity is associated with Serra da Portaria that is also characterized by dykes that cut the sandstone and resemble portals.

Figure 7. Abandoned area Muralha de Ferro a possible important tourist area.

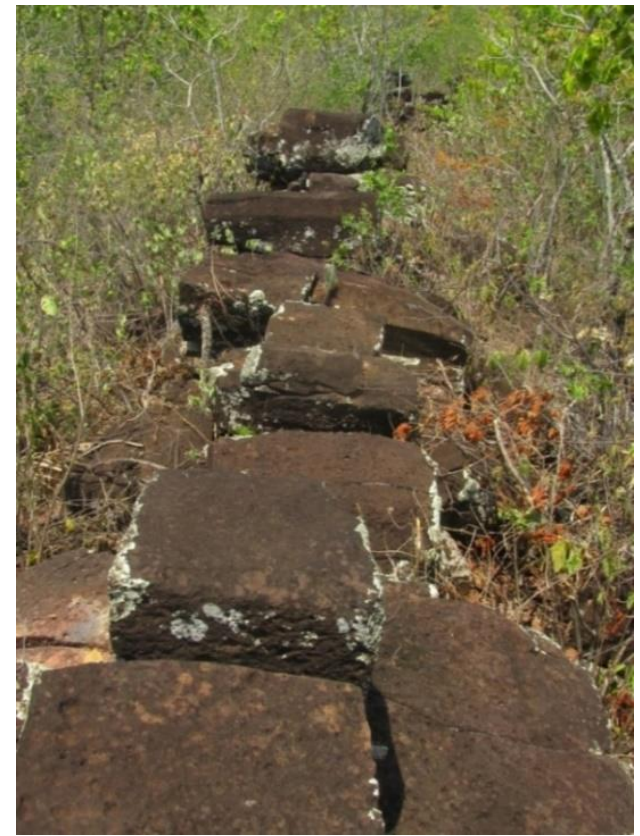

Source: Ferreira (2016). 
This Geodiversity site has erosive processes or displacement of sandstone blocks from the Aquidauana Formation. It does not present restrictions on its use. Currently, its access is difficult due to road and poor safety conditions. This site is an area visited by educational institutions for presenting decent geological strata that are used by teachers.

\section{Geodiversity Site 7: Serra das Galés}

The Serra das Galés (Figure 8) is $28 \mathrm{~km}$ from Paraúna. To Figueiredo and Olivatti (1974) it is noticeable the presence of argillite, siltite, and fine sandstone in the monuments of Serra das Galés. The monuments are rocks sculpted over the years by environmental weathering, having many forms of aesthetic value. The cultural value of Serra das Galés is given by the religious belief of local population that uses the area for religious purposes.

Figure 8. Typical sculped scenary in the Serra das Galés Geodiversity site.

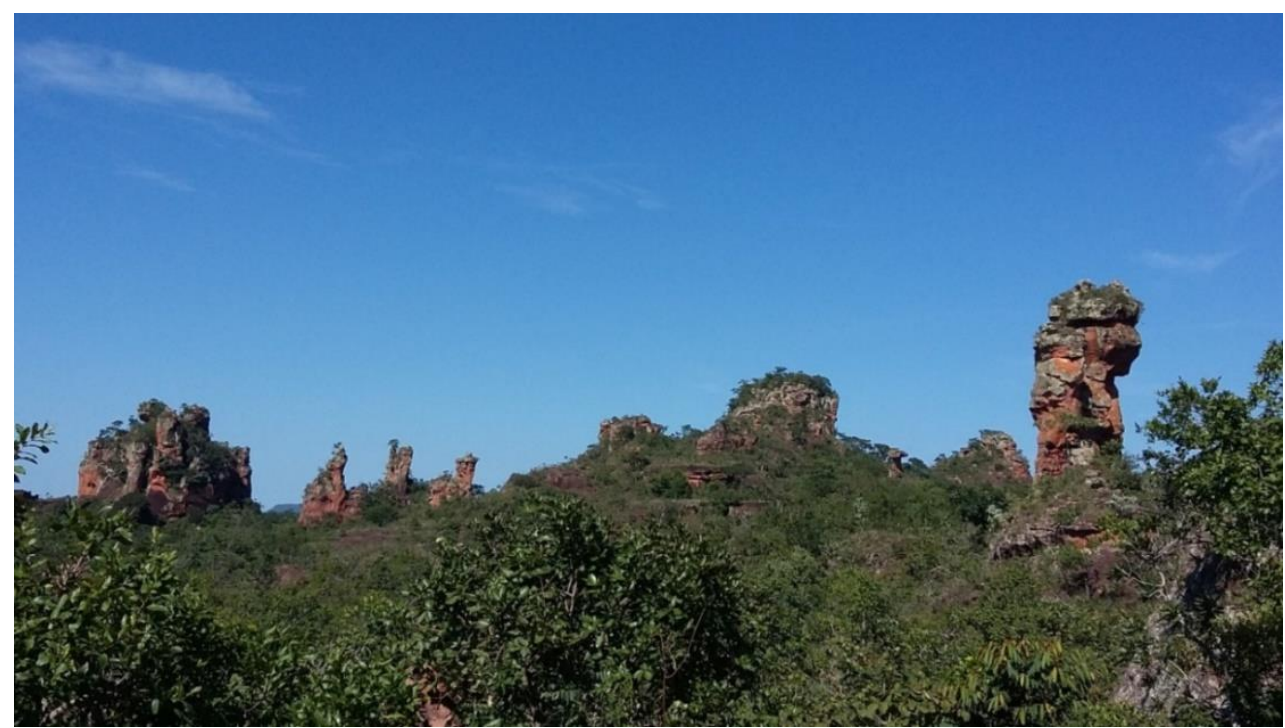

From: Ferreira (2016).

The Tourist Diagnosis of Paraúna (2007b) describes Serra das Galés having a total area of 271 ha composed by sets of sandstone forming monuments named Cálice (Goblet), Tartaruga (Turtle), Índia (Indian Woman), Três Reis Magos (the Three Wise Men), Lagartixa (Gecko), Bigorna (Anvil), Cérebro de Pedra (Stone Brain), among others. According to Goiás (2008), these monuments were shaped by differential erosion on several levels, which allowed the formation of "testimony hills" that resemble other objects. The names of these geoforms were given by local residents and refer to elements of the local culture.

The geoforms Cérebro (Figure 9A) and Lagartixa (Figure 9B) are similarly shaped especially for being cylindrical. From a specific point at the top of the geoforms down to their bases, both monuments suffered similar erosive processes. However, the top of both geoforms suffered a more intense weathering resulting in smaller and thinner sandstone structures.
The geoforms Três Reis Magos (Figure 10A) and Índia (Figure 10B) present sharp edges at the top of the sandstone walls. These were formed by the combination of erosive processes and the dissolution and removal of sandstone grains that removed the most fragile parts and exposed more resistant areas of the rock. These features are visually interpreted by observers as an indian woman facing the horizon (Figure 10B) and the Three Wise Men on their way to meet Jesus Christ on the night of His birth (Figure 10A).

According to tourist guides, the geoform Cálice (Figure 11A) is the most visited by tourists. It is a sandstone column with an enlarged top and a narrow base, shaped after differential erosion where the main erosive agent is the rainwater flow that dissolves soluble minerals and removes sandstone grains. Overall, fractures may lead to the isolation of these structures. Like the previous geoforms, the name Cálice was coined by local residents due to its similarity to a globet. 
Figure 9. Geoforms of sandstones named, (A) Cérebro and (B) Lagartixa.

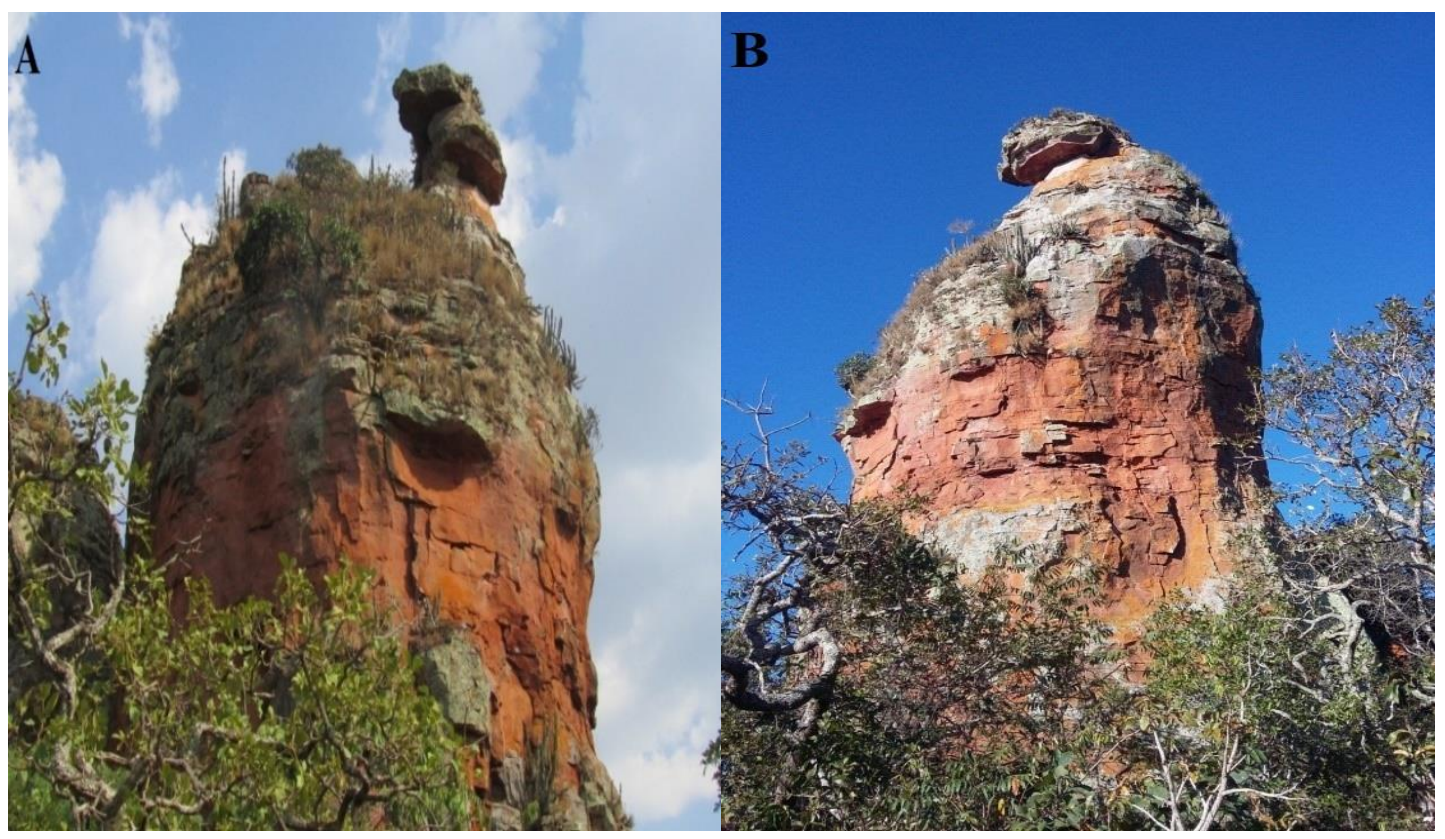

Source: Ferreira (2016).

The geoform Tartaruga (Figure 11B), also a result of sandstone weathering, instigates the curiosity of its visitors as well. The angular shape at the top of the structure resembles the shell of a turtle and the small elevations are seen as the head and the tale of the turtle. Local residents believe that the turtle is asleep and was petrified millions of years ago, and may return to life someday.

The geoforms of Serra das Galés are not geologically neither geomorphologically unique. In the municipality of Vila Velha, Paraná State, there are some geoforms similar to the ones from Paraúna. The geoforms of both localities are sandstone rocks that belong to the same geological unity of the Itararé Group (Aquidauana Formation, Paraná Basin) and are shaped as objects and animals (LETENSKI, et al. 2009; MELO, 2009).

Figure 10. Geoforms of sandstones named (A) Três reis magos and (B) Índia.

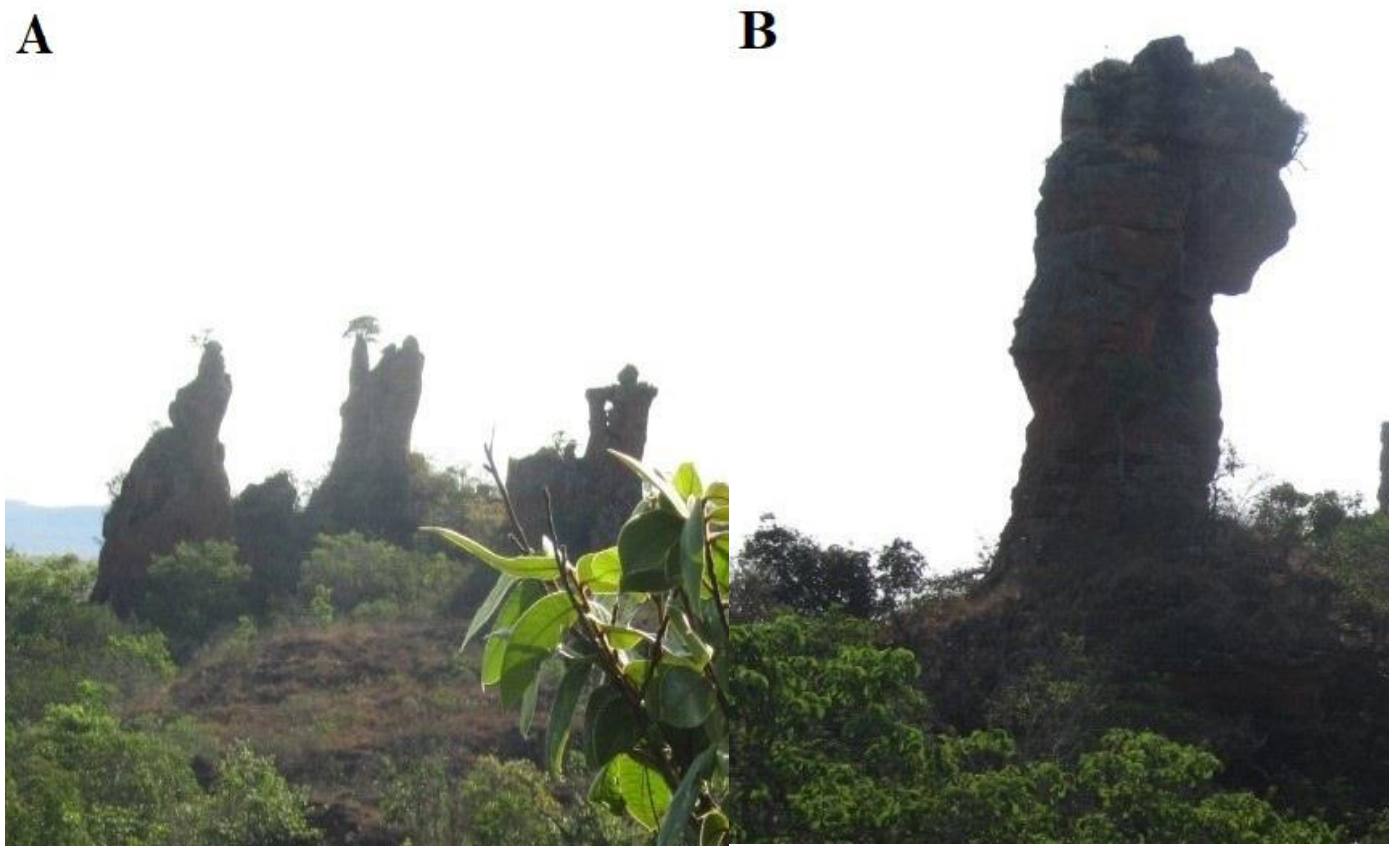

Source: Ferreira (2016). 
Figure 11. Geoforms of sandstones named, (A) Cálice and (B) Tartaruga.

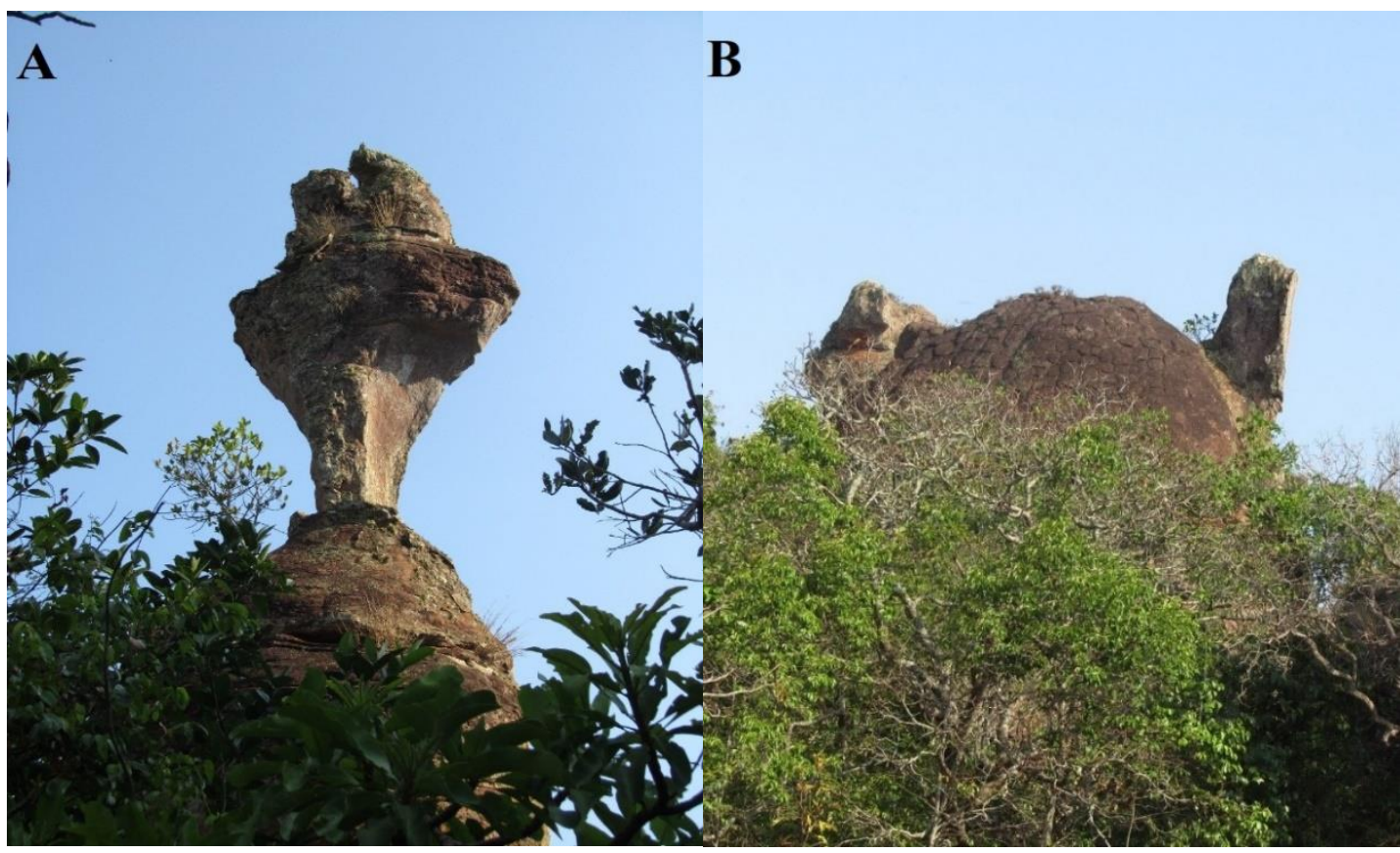

Source: Ferreira (2016).

Nonetheless, culturally, the population has many opinions and beliefs that lead to different impressions of these shapes. Each geoform can be interpreted according to the individual's perspective and, thus, what it looks like a goblet to one person may appear like an animal to another

This Geodiversity site has erosive processes or displacement of sandstone blocks from the Aquidauana Formation. There are no restrictions on its use and it is visited by residents and tourists from Paraúna. Its access and security are considered as intermediate. It is highly visited by educational institutions for presenting decent geological strata that are used by teachers.

\section{FINAL CONSIDERATIONS}

The region is economically important to the state due the production and exportation of leguminous grains.

The natural physical features of Paraúna include rocks that are dated from the Neoproterozoic period. Yet, it is noteworthy the occurrence of a part of the Paraná sedimentary basin since its lithology shaped the topography of the municipality of Paraúna. Geomorphologically, the rocks of the Paraná Basin underwent regional planation processes. The dominant units are the regional planation surfaces associated with tabular reliefs. The vegetation of Paraúna is mainly part of the Cerrado biome.
The Geodiversity inventory of the municipality of Paraúna presented here includes seven representative Geodiversity sites with geological settings of the analyzed territory. The list of sites included in this work can (and should) be expanded and improved following the experience of different research groups, the educational development of the region, and the potential geoscientific interest of the area. The present study revealed the most relevant geological elements in terms of educational value and tourist value. This analysis allows us to recognize that the Paraúna Geodiversity sites present the basic requirements to be considered as a geological heritage (geological and geomorphological).

This study addressed a new theme in the Geosciences: geodiversity. The geodiversity is the diversity of elements of the natural physical environment. It is an integral part of our planet and, thus, preservation is important so that future populations have the chance to know such elements. This research identified several Geodiversity sites in the northern region of Paraúna. Each Geodiversity site has its specificity with different natural elements such as waterfalls, hills, stone walls, and caves. Because they are tourist spots, these areas are periodically visited, however, some localities lack adequate infrastructure to receive tourists. In addition, some Geodiversity sites are subject of popular mysticism and are of relevant cultural value, which stimulate the creation of beliefs among the population. 


\section{REFERENCES}

AB'SABER, A. N. O domínio dos cerrados: introdução ao conhecimento. R. Serv. Brasília, 1983.111:41-55. Brasília, DF

BORBA A.W., SOUZA L.F., MIZUSAKI A.M.P., ALMEIDA, STUMPF P.P. Inventário e avaliação quantitativa de geossítios: exemplo de aplicação ao patrimônio geológico do Município de Caçapava do Sul (RS, Brasil).. Pesq. Geoc., 40(3) : 275294. 2013. https://doi.org/10.22456/1807 9806.77830

BRILHA, J. B. R. Patrimônio geológico e geoconservação: a conservação da natureza na sua vertente geológica. Lisboa: Editora Palimage, 2005. 190 p.

Inventory and Quantitative Assessment of Geosites and Geodiversity Sites: a review. Geoheritage, v.8, n.2, p.119-134, jun. 2016 . https://doi.org/10.1007/s12371-014-0139-3

CASSETI, V. Geomorfologia (Livro digital). 2005.

DIAS-BRITO, D.; MUSACCHIO, E. A. ; CASTRO, J. C. ; MARANHÃO, M. S. A. S. Grupo Bauru: uma unidade continental do Cretácio do Brasil - Concepções baseadas em dados micropaeontológicos, isotóplicos e estratigráficos. Revue Paléobiologie, Genebra, v.20, p. 245-304, 2001.

FERNANDES, L. A.; COIMBRA, A. M. A Bacia Bauru (Cretáceo Superior, Brasil). Anais da Academia Brasileira de Ciências, Rio de Janeiro, v. 68, n. 2, p. 195-205, jul. 1996.

FIGUEIREDO, AJ.A. \& OLIVATTI, O. Projeto Alto Guaporé.Goiânia, DNPM/CPRM. v. I, p. $173,1974$.

FERREIRA, B. M. Geodiversidade no Município de Paraúna/Goiás. 2016. Dissertação (Mestrado em Geografia) Programa de Pós Graduação em Geografia, Universidade Federal de Goiás, Goiânia, 2016.

FERREIRA, B. M.; LIMA, C. V. . Aspectos naturais do Parque Estadual de Paraúna em Goiás. In: o IX Simpósio Nacional de Ciência e Meio Ambiente, 2018, Anápolis. Anais do IX Simpósio Nacional de Ciência e Meio Ambiente. Unievangélica, Anápolis, 2018.

Disponivel.

http://anais.unievangelica.edu.br/index.php/ CIPEEX/article/view/3018 Acesso em 18 de janeiro de 2020.

GRAY, M. Geodiversity: valuing and conserving abiotic nature. Wiley and
Sons, Chichester, 2004.

GOIÁS (Governo do Estado de Goiás). Secretaria de Indústria e Comércio. Superintendência de Geologia e Mineração. Geologia do Estado de Goiás e do Distrito Federal. Por MOREIRA, Maria Luiza Osório; et al. Goiânia, GO. 2008.

Decreto 5.568, de 18 de março de 2002. Criação do Parque Estadual de Paraúna. Goiás, Goiânia, 18 mar. 2002.

. Geomorfologia do Estado de Goiás e do Distrito Federal. Por Latrubesse, E. M; Carvalho, T. M. Goiânia, GO. 2006.

Secretaria de Estado de Meio Ambiente e Desenvolvimento Sustentável. Parque Estadual de Paraúna. Disponível. https://www.meioambiente.go.gov.br/planose-projetos/agenda-2030-ods/118-meioambiente/unidades-de-

conserva\%C3\%A7\%C3\%A3o/1105-parqueestadual-de-parauna-pepa.html. Acesso em 10 de janeiro de 2019.

IBGE - Instituto Brasileiro de Geografia e Estatística. Censo de 2010. Pesquisa Nacional por Amostra de Domicílios. Rio de Janeiro: IBGE; 2011. Disponível. https://biblioteca.ibge.gov.br/index.php/biblio teca-catalogo? view $=$ detalhes $\& i d=249230$ Acesso em 15 de janeiro de 2019.

LACERDA, H.; SANTOS V. C.; GOMES V. F. Mapa geomorfológico preliminar da região da Serra das Galés e Serra da Portaria, Paraúna (GO). In: VI Seminário de Pesquisa de Professores e VII Jornada de Iniciação Científica da Unidade de Ciências Socioeconômicas e Humanas de Anápolis UnUCSEH/Universidade Estadual de Goiás. 2011. Anápolis, ANAIS. Anápolis: UEG, 2013. 1 CD-ROM

LETENSKI, R.; GUIMARÃES, G.B.; PIEKARZ, G.F.; MELO, M.S. Geoturismo no Parque Estadual de Vila Velha: nas trilhas da dissolução. Pesquisas em Turismo e Paisagens Cársticas: Campinas, SBE, v. 2, n.1, p.5-15. 2009

MELO, M. S. de. Formas rochosas do Parque Estadual de Vila Velha. 1. ed. Ponta Grossa: Editora da Universidade Estadual de Ponta Grossa, 2006. v. 1. 145p .

MILANI, E. J.; FACCINI, U. F. ; SCHERER, C. M. S. ; ARAUJO, L. M. ; CUPERTINO, J. A. . Sequences and stratigraphic hierarchy of the Paraná Basin (Ordovician to Cretaceous), Southern Brazil. Boletim do ig-usp, São Paulo, v. 29, p. 125-173, 1998. https://doi.org/10.11606/issn.23168986.v29i0p125-173

PARAÚNA. Inventário Turístico do 
Município de Paraúna - GO. ParaúnaGoiás, 2007a.

Diagnóstico turístico e plano de ação do município de PARAÚNA- GO. Paraúna-Goiás, 2007b.

Paraúna-Goiás, 2013.

RADAMBRASIL. Folha SF.21 Campo Grande. Ministério das Minas e Energia Departamento Nacional da Produção Mineral. Levantamentos de Recursos Naturais. Rio de Janeiro, 1982. v.28.

REYNARD, E. BRILHA, J. Geoheritage: a multidisciplinary and applied research topic. In: Reynard E, Brilha J (eds) Geoheritage: assessment, protection, and management. Elsevier, Amsterdam, 2018. p 433-438. https://doi.org/10.1016/B978-0-12809531-7.00025-3

RIBEIRO, J. F. e WALTER, B. M. T. As principais fitofisionomias do bioma Cerrado in: SANO, S. M.; DE ALMEIDA, S. P., RIBEIRO, J. F. Cerrado Ecologia e Flora. Brasília: Embrapa Informação Tecnológica, 2008, $406 \mathrm{p}$.

ROSETTI., L.M.M. ; LIMA, E. F. DE ; WAICHEL, B. L. ;SIMÕES, M.S. ; SCHERER, C. M. ; HOLE, M. J. . Lithostratigraphy and Volcanology of the Serra Geral Group, Paraná-Etendeka Igneous Province in Southern Brazil: Towards a Formal Stratigraphical Framework. JOURNAL OF VOLCANOLOGY AND GEOTHERMAL RESEARCH, v. 355, p. 98-114, 2018. https://doi.org/10.1016/j.jvolgeores.2017.05.0 08

SCHNEIDER, R.L.; MÜHLMANN, H.; TOMMASI, E.; MEDEIROS, R. A.; DAEMON, R. F.; NOGUEIRA, A. A. Revisão estratigráfica da Bacia do Paraná. In: CONGRESSO BRASILEIRO DE GEOLOGIA, 28, Porto Alegre, 1974. Anais... Porto Alegre : SBG , 1974. v. 1, p.41-65.

STANLEY, M. Geodiversity. Earth Heritage, v. 14 , p. $15-18,2000$.

SUAREZ, J. M. ; RODRIGUES, R. . Grupo Bauru: uma unidade continental do Cretáceo no Brasil - concepções baseadas em dados micropaleontológicos, isotópicos e estratigráficos. Revue de Paléobiologie, Suíça, v. 20, n.1, p. 245-304, 2001. 